\title{
TOXICITY IMMOBILIZATION OF REFINERY SLUDGE CONTAINING HEAVY METALS VIA VITRIFICATION PROCESS
}

\author{
Salmiaton Ali ${ }^{1}$, Aida Isma Mohd. Idris ${ }^{2}$, Hazmin Mansor ${ }^{3}$ \\ ${ }^{1}$ Assoc. Prof. Dr., Department of Chemical and Environmental Engineering, Faculty of Engineering, \\ Universiti Putra Malaysia, 43400 UPM Serdang, Selangor, Malaysia \\ ${ }^{2}$ Miss, School of Engineering, SEGi University College, 47680 Kota Damansara, Selangor, Malaysia, \\ ${ }^{3}$ Miss, Faculty of Engineering, Selangor University, 45600 Bestari Jaya, Selangor, Malaysia, \\ mie@upm.edu.my, aidaisma@hotmail.com,hazmin@unisel.edu.my
}

\begin{abstract}
Heavy metals are known to be toxic to human and the environment. Despite the growing of petrochemical and refinery industries, the world is facing problems with the heavy metals contamination from the sludge by the industries. Many methods have been applied to address these issues from the refinery sludge. In this study, stabilization and solidification of refinery sludge containing heavy metals using vitrification method was utilized to solve this problem. The ashing temperature of $550^{\circ} \mathrm{C}$ was selected in preparing the ash of the dried sludge prior to the vitrification process at $1110^{\circ} \mathrm{C}$ to $1400^{\circ} \mathrm{C}$. After vitrification, all samples were morphologically, thermally and toxically analyzed using Scanning Electron Microscopy, Thermogravimetric Analysis and Toxicity Characteristic Leaching Procedure. The sludge contained high amount of iron and aluminum, followed by some amount of magnesium, gold, arsenic and zinc with some traces of nickel and lead. Results showed that at maximum vitrified temperature of $1400^{\circ} \mathrm{C}$, no magnesium, nickel and lead were detected in the sludge and only some traces of other heavy metals with less than 1 ppm. The vitrification method exhibits excellent output in immobilizing the transition metals leading to a reduction in environmental pollution caused by petrochemical and refinery sludge containing heavy metals.
\end{abstract}

Index Terms: Vitrification, Heavy metals contamination, Refinery sludge, Toxicity, Leaching analysis

\section{INTRODUCTION}

Increasing population, consumerism and industrial development have led to an increase in the quantities of hazardous and municipal solid waste (MSW) generated worldwide. Various thermal processes, including incineration, pyrolysis, melting or vitrification have been proposed for treating these hazardous wastes prior to disposal aiming to destroy the organic fraction and convert the inorganic fraction into an inert silicate slag, or glass, that can either be advantageously reused, or harmlessly disposed of in an inert landfill $[1,2]$.

Plasma pyrolysis or vitrification (PP/V) process is a unique thermal treatment of wastes that has been implemented and is growing rapidly. Vitrification process on petrochemical sludge is a potential new approach for solid waste management as it has been proved to be the one of the most promising and lowcost methods for the stabilization and solidification of hazardous solid wastes. It has been applied for various urban, industrial and radioactive wastes [3-5].

Vitrification concentrates a number of important merits such as large waste volume reduction, low cost application, negligible mass of by-products and the ability to produce marketable materials. The toxic elements and chemical substances can either participate on the formation of the glass network or be captivated in the form of precipitates or crystal in the glass network [6]. This study aims to establish a vitrification treatment by which heavy metal contents in the sludge is stabilized and transformed into stable solidified form at the same time.

\section{MATERIALS AND METHODS}

\subsection{Materials}

In this study, the refinery sludge was obtained from a local refinery treatment plant located in Melaka, Malaysia. For the acid digestions, 38\% nitric acid supplied by Evergreen Sdn. Bhd. was used for heavy metal composition from the refinery sludge before vitrification process whereas for toxicity characteristic leaching procedure (TCLP), acetic acid supplied by the same company was used for heavy metal determination after the vitrification process.

\subsection{Proximate Analysis}

Proximate analysis and ash temperature on a dried basis were determined using Thermogravimetric Analyzer (TGA, 
SDTA851, Mettler Toledo, USA) with heating and cooling rate of $5^{\circ} \mathrm{C} / \mathrm{min}$ at $50 \mathrm{~mL} / \mathrm{min} \mathrm{N}_{2}$ as inert gas purging. Approximately $10 \mathrm{mg}$ of sludge was placed in the TGA and $\mathrm{N}_{2}$ gas $\left(50 \mathrm{~cm}^{3} \mathrm{~min}^{-1}\right)$ was allowed to flow from room temperature to $150^{\circ} \mathrm{C}$ for moisture content estimation. The TGA was then set to $450^{\circ} \mathrm{C}$ to estimate volatile matter in the sludge. TGA containing sludge was then cooled to $350^{\circ} \mathrm{C}$ before switching to air stream and was then heated to $900^{\circ} \mathrm{C}$ for ash content. This step could also be used to estimate the ash temperature. The TGA analysis was repeated three times for consistency and reproducibility.

\subsection{Ashing Sample}

Crucible before and after containing dried sludge was weighed and recorded Then, the crucible containing dried sludge (dried previously at $105^{\circ} \mathrm{C}$ for 1 to 2 days) was heated in the furnace at a rate of $5^{\circ} \mathrm{C} / \mathrm{min}$ to the desired ashing temperature obtained from proximate analysis for 16 hours to ensure all organics content was eliminated. Then, the sample was set to cool down to room temperature in the furnace. The crucible containing ash sample was weighed and recorded.

\subsection{Heavy Metal Determination}

Dried sludge was mixed with $38 \%$ nitric acid via acid digestion according to US EPA method 3050B [7]. The mixture was heated to $70-80^{\circ} \mathrm{C}$ for two hours for digestion to take place. The, the filtrate was taken for heavy metal determination using Inductively Couple Plasma (ICP-OES, Perkin Elmer Optima 7300DV, USA). The process was repeated three times for consistency and reproducibility.

\subsection{Vitrification Process}

The ash samples were vitrified in the furnace at temperature ranges from 1100 to $1400^{\circ} \mathrm{C}$ for 2 hours with a constant rate of $5^{\circ} \mathrm{C} / \mathrm{min}$, followed by a cooling stage until room temperature was achieved.

\subsection{TCLP Analysis}

The toxicity characteristic leaching procedure was adopted from US EPA Hazardous Amendments of 1984. The vitrified material was crushed into particle size less than $9.5 \mathrm{~mm}$ prior to leaching process. The crushed material was then mixed with diluted acetic acid and water to a $\mathrm{pH}$ of $2.88 \pm 0.05$ in a liquid to solid weight ratio of $20: 1$. The $\mathrm{pH}$ mentioned above was being chosen due to its acidic condition commonly found in landfill. The sample was stirred for 18 hours at $30 \mathrm{rpm}$ and $22^{\circ} \mathrm{C}[8]$.

\subsection{Morphology Analysis}

A scanning electron microscope equipped with an EDX detector (SEM, Hitachi S 3400N, and Japan) was used to examine the texture and chemical elements present on the surface of the samples.

\section{RESULTS AND DISCUSSIONS}

\subsection{Chemical Characteristics of Raw Sludge}

The proximate analysis and ash temperature were obtained from the thermal analysis via TGA. The total weight loss was $87.37 \%$ with moisture content of $76.71 \%$ and volatile matter of $10.66 \%$. The estimated ash temperature was $550^{\circ} \mathrm{C}$. The moisture content obtained from this refinery sludge was in the range obtained by Lin et al. [9]. Chart 1 shows the thermal analysis on the dried sludge.

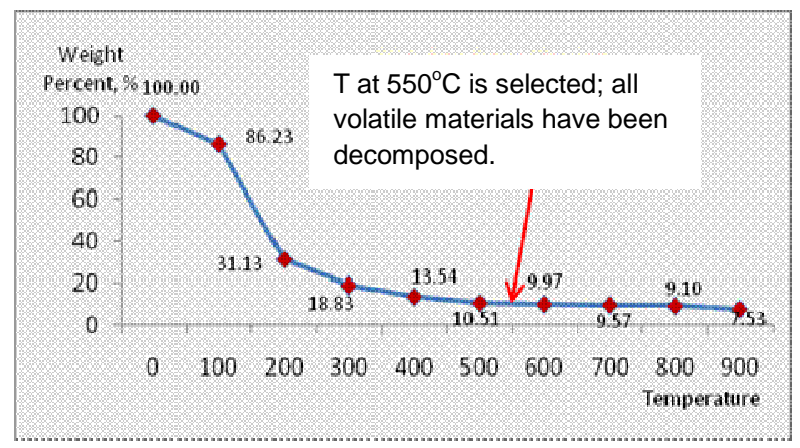

Chart -1: Ash temperature determination from the thermal analysis

Table 1 presents the metal compositions obtained in the digestate raw sludge via ICP analysis. Eight heavy metals namely $\mathrm{Fe}, \mathrm{Al}, \mathrm{Mg}, \mathrm{Au}, \mathrm{As}, \mathrm{Zn}, \mathrm{Pb}$ and $\mathrm{Ni}$ were detected. These compositions as tabulated in Table 1 were generally similar to those found by Lin et al. [9] and Brown et al. [10]. The concentrations of the heavy metals detected were compared with the Malaysia Environmental Quality Assurance (EQA) standard.

Table -1: Heavy metals concentrations of raw sludge and EQA limits (ppm)

\begin{tabular}{ccccccccc}
\hline Analyte (ppm) & $\mathrm{Fe}$ & $\mathrm{Al}$ & $\mathrm{Mg}$ & $\mathrm{Au}$ & $\mathrm{As}$ & $\mathrm{Zn}$ & $\mathrm{Pb}$ & $\mathrm{Ni}$ \\
\hline Average conc. & 349.40 & 103.91 & 41.47 & 30.08 & 26.95 & 25.82 & 1.89 & 1.66 \\
& \pm 76.40 & \pm 14.29 & \pm 8.40 & \pm 0.22 & \pm 0.35 & \pm 2.09 & \pm 1.27 & \pm 2.79 \\
EQA standard & 5.00 & $\mathrm{NA}$ & 0.20 & $\mathrm{NA}$ & 0.05 & 2.00 & 0.10 & 0.20 \\
\hline \multicolumn{7}{c}{ NA - not regulated }
\end{tabular}

\subsection{Morphology Analysis}

The vitrified samples in the range of $1110-1400^{\circ} \mathrm{C}$ were initially examined through naked eyes for the completeness of the melting and the smoothness of the samples. As shown in Fig. 1(a) and (b), both temperatures were not sufficient enough 
to cause the refinery ash to completely melt leading to rough surface of the vitrified samples. The incompleteness of the melting could cause the in homogeneity of the vitrified sample leading to enhancement of the heavy metal leaching. Fig. 1(c), (d) and (e) show a complete melting of the vitrified samples with smooth surface could be observed.

The vitrification process was re-examined in the narrower temperature range of $1320-1400^{\circ} \mathrm{C}$, as shown in Fig. 2. As can be seen in all figures, the surfaces were smooth with Fig. 2(c) and (d) the smoothest, which could be considered good since the ash samples were completely melted producing shiny and smooth vitrified material. The vitrified materials were morphologically examined using Scanning Electron Microscope as presented in Fig. 3.

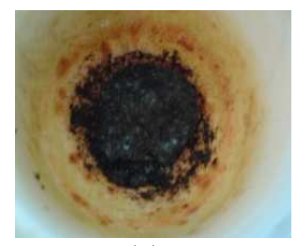

(a)

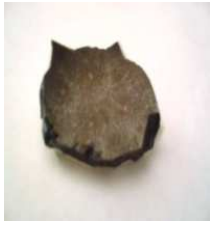

(d)

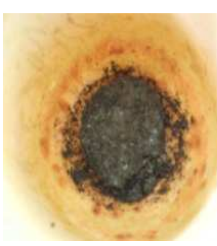

(b)

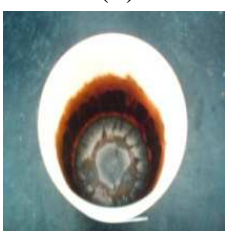

(e)

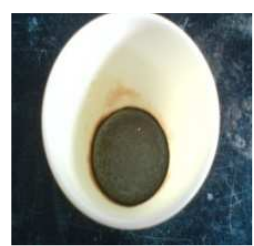

(c)

Fig -1: Vitrification at temperature: (a) $1100^{\circ} \mathrm{C}$, (b) $1200^{\circ} \mathrm{C}$, (c) $1300^{\circ} \mathrm{C}$, (d) $1350^{\circ} \mathrm{C}$, (e) $1400^{\circ} \mathrm{C}$

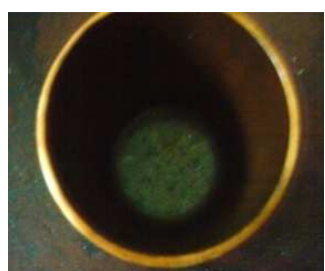

(a)

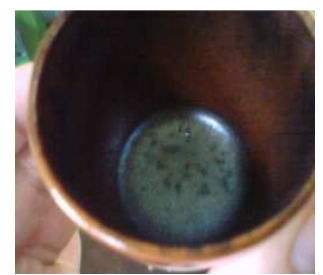

(c)

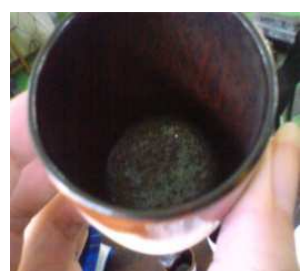

(b)

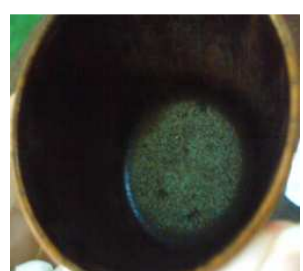

(d)

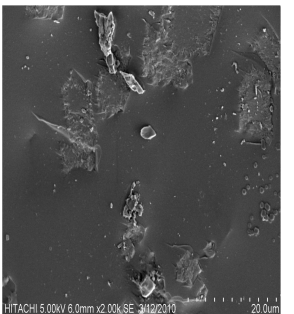

(a)

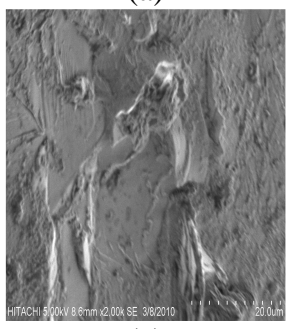

(c)

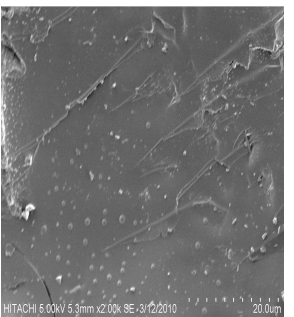

(b)

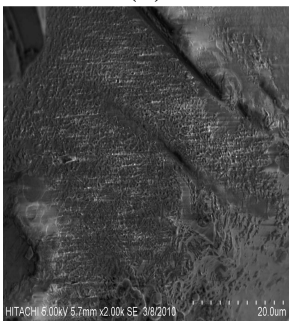

(d)
Fig -3: SEM microphotograph at magnification 2000 times with vitrified temperature at (a) $1320^{\circ} \mathrm{C}$ (b) $1350^{\circ} \mathrm{C}$

(c) $1380^{\circ} \mathrm{C}$ (d) $1400^{\circ} \mathrm{C}$

From the image, it should be noted that some uneven surface were seen reflecting the existent of contaminants. Vitrified material at $1380^{\circ} \mathrm{C}$ (Fig. 3(c)) reveals that the solid produced has a non-glass morphology under 2000 times image magnification. The probable material could be the left over organic matters, metals or organometals materials. Fig. 3(d) portrays a stable and smooth surface at vitrification temperature of $1400^{\circ} \mathrm{C}$. The vitrified material at $1350^{\circ} \mathrm{C}$ was further tested using EDX to determine the existence of chemical elements on the surface as tabulated in Table 2.

Fig -2: Vitrification at temperature: (a) $1320^{\circ} \mathrm{C}$, (b) $1350^{\circ} \mathrm{C}$,

(c) $1380^{\circ} \mathrm{C}$, and (d) $1400^{\circ} \mathrm{C}$ 
Table -2: Weight percentage of elements found in vitrified refinery sludge at $1350^{\circ} \mathrm{C}$

\begin{tabular}{|c|c|c|c|}
\hline \multicolumn{2}{|c|}{ 'Element } & Point 1 & Point 2 \\
\hline \multirow{4}{*}{ Non-metals } & $C^{*}$ & 4.32 & 9.60 \\
\hline & $O^{*}$ & 39.96 & 37.34 \\
\hline & $S i^{*}$ & 7.25 & 4.87 \\
\hline & $S i *$ & --- & --- \\
\hline \multirow{23}{*}{ Metals } & $M g *$ & 3.09 & 2.81 \\
\hline & $A l^{*}$ & 5.59 & 5.08 \\
\hline & $K^{*}$ & 0.64 & 0.30 \\
\hline & $K^{*}$ & --- & --- \\
\hline & $C a^{*}$ & 9.01 & 5.91 \\
\hline & $C a^{*}$ & --- & --- \\
\hline & $\boldsymbol{F e}^{*}$ & 17.42 & 22.61 \\
\hline & $\boldsymbol{F e}^{*}$ & --- & --- \\
\hline & $\mathrm{Co}^{*}$ & --- & --- \\
\hline & $\mathrm{Co}^{*}$ & --- & 1.38 \\
\hline & $\mathrm{Cu}^{*}$ & --- & --- \\
\hline & $C u^{*}$ & 4.29 & 3.31 \\
\hline & $Z n *$ & --- & --- \\
\hline & $Z n *$ & 2.94 & 1.88 \\
\hline & $I^{*}$ & 0.30 & 0.62 \\
\hline & $I^{*}$ & --- & --- \\
\hline & $B a^{*}$ & 1.56 & --- \\
\hline & $B a^{*}$ & --- & --- \\
\hline & $I r^{*}$ & --- & --- \\
\hline & $I r^{*}$ & 3.64 & 2.41 \\
\hline & $I r^{*}$ & --- & --- \\
\hline & $T l^{*}$ & & 1.87 \\
\hline & $T l^{*}$ & & --- \\
\hline \multicolumn{2}{|c|}{ Total } & 100.00 & 100.00 \\
\hline
\end{tabular}

Two points were taken to be elementally tested. Under the non-metals group, oxygen had the highest average weight percentage of $38.65 \%$ from the overall weight of vitrified material whereas carbon had the lowest average percentage of $6.96 \%$ During vitrification, high temperature causes the oxygen to escape from metals oxide to form glass structure leading to high concentration of oxygen. The carbon concentration on the other hand is the lowest among nonmetals since the element may combine with the oxygen to form carbon dioxide during vitrification process. For the metals group, iron is expected to have the highest weight percentage, similar trend showed by the ICP analysis. The most important finding is that ICP analysis indicates iridium (Ir) as gold $(\mathrm{Au})$. This might be due to (i) no available standard solution for indium in the ICP analysis and gold in the EDX and (ii) the ICP spectrum for both are close to each other.

Even though both values for point 1 and point 2 are not the same, the trend is quite similar indicating some elements have not been completely melted during the vitrification process, leading to identified elements using EDX.

\subsection{TCLP Analysis}

The TCLP results on the vitrified material at vitrified temperature of $1320-1400^{\circ} \mathrm{C}$ are shown in Table 3 . The results revealed that all traced elements were within the EQA standard, except arsenic (As). As shown in the table, the concentrations in the vitrified sample were significantly lower than the metal concentrations in the raw sludge. Some traced elements are possibly due to (i) inhomogeneously mixed prior to ashing and vitrification process leading to incomplete melt, (ii) higher melting temperature in comparison to tested vitrification temperatures for example iron and nickel, and (iii) spectrum mixed up between gold and iridium. In general, chemical stability is consistent with the progressive formation of more compact and interconnected glass network structure [4]. Therefore, vitrification of refinery sludge waste resulted in the reduction of metal leachability.

Table -3: Traced metals of vitrified material

\begin{tabular}{|c|c|c|c|c|c|c|c|}
\hline \multirow[b]{2}{*}{ Analyte } & \multirow{2}{*}{$\begin{array}{c}\text { Melting } \\
\text { Temperature } \\
\left({ }^{\circ} \mathrm{C}\right)\end{array}$} & \multicolumn{6}{|c|}{ Concentration (ppm) } \\
\hline & & $\begin{array}{l}\text { Initial } \\
\text { sludge }\end{array}$ & $\begin{array}{c}\text { EQA } \\
\text { standard }\end{array}$ & $\begin{array}{l}\text { Vitrified } \\
1320^{\circ} \mathrm{C}\end{array}$ & $\begin{array}{l}\text { Vitrified } \\
1350^{\circ} \mathrm{C}\end{array}$ & $\begin{array}{l}\text { Vitrified } \\
1380^{\circ} \mathrm{C}\end{array}$ & $\begin{array}{l}\text { Vitrified } \\
1400^{\circ} \mathrm{C}\end{array}$ \\
\hline $\mathrm{Fe}$ & 1535 & 349.40 & 5.00 & 0.14 & 0.31 & 0.54 & 0.26 \\
\hline $\mathrm{Al}$ & 660.4 & 103.91 & NA & 1.81 & 1.55 & 2.45 & 1.15 \\
\hline $\mathrm{Mg}$ & 650 & 41.47 & 0.20 & 0.00 & 0.00 & 0.00 & 0.00 \\
\hline $\mathrm{Au} / \mathrm{Ir}$ & 1064 & 30.08 & NA & 0.71 & 0.71 & 0.71 & 0.71 \\
\hline As & 816.8 & 26.95 & 0.05 & 0.03 & 0.05 & 0.06 & 0.07 \\
\hline $\mathrm{Zn}$ & 419.6 & 25.82 & 2.00 & 0.47 & 0.46 & 0.45 & 0.45 \\
\hline $\mathrm{Pb}$ & 327.5 & 1.90. & 0.10 & 0.00 & 0.00 & 0.00 & 0.00 \\
\hline $\mathrm{Ni}$ & 1453 & 1.66 & 0.20 & 0.00 & 0.00 & 0.00 & 0.00 \\
\hline
\end{tabular}

\section{CONCLUSIONS}

The ash, moisture and organic content of refinery sludges were found to be $12.63 \%, 76.71 \%$ and $10.66 \%$, respectively. Ash temperature was found to be $550^{\circ} \mathrm{C}$. The solid residues obtained after vitrification treatments exhibited a considerably lower leaching of heavy metals contents than the raw refinery sludge with a smooth surface morphology obtained at vitrified temperature of 1380 and $1400^{\circ} \mathrm{C}$. Some improvements can be made such as thoroughly mix prior to ashing and vitrification, and higher tested temperatures for melting completeness resulting more smooth morphology and untraced heavy metals during TCLP analysis for wider application such as window panel. Consequently, vitrification process shall represent a reliable environmental friendly and safe solution for managing, stabilizing and converting refinery sludge containing heavy metals into useful products.

\section{ACKNOWLEDGEMENTS}

The authors would like to thank Miss Michelle Lim for the analysis and Faculty of Engineering, Universiti Putra Malaysia for the facility. 


\section{REFERENCES}

[1]. Colombo P, Brustin G, Bernardo E \& Scarinci G, Current Opinion in Solid State and Material Science, 7 (2003) 225.

[2]. Kavouras P, Komninou Ph \& Karakostas Th, Journal of the European Ceramic Society, 24 (2004) 2095.

[3]. Gomez E, Amutha Rani D, Cheeseman C R, Deegan D, Wise M \& Boccaccini A R, Journal of Hazardous Materials, 161 (2009) 614.

[4]. Park Y J \& Heo J, Journal of Hazardous Materials, 91 (2002) 83.

[5]. Israel A U, Obot I B, Umoren S A, Mkpenie V \& Ebong GA, E-Journal of Chemistry, 5 (2008) 74.

[6]. Bingham P A \& Hand R J, "Journal of Hazardous Materials, 119 (2005) 125.

[7]. Eaton A D, Clesceri L S, Rice E W \& Greenberg A E, Standard Methods for the Examination of Water and Wastewater, 21st Edition (American Public Health Association, USA), 2005, 101.

[8]. LaGrega M D, Buckingham P L \& Evans J C, Hazardous Waste Management (McGraw-Hill, Boston), 2001, 172.

[9]. Lin K -H, Hsu H -T, Ko Y -W, Shieh Z -X \& Chiang H L, Journal of Hazardous Materials, 171 (2009) 208.

[10.] Brown K W \& Donnelly K C, Environmental Pollution Series B: Chemical and Physical, 6 (1983) 119.

\section{BIOGRAPHIES}

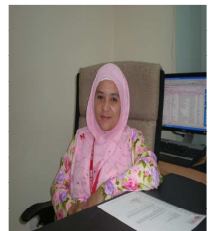

Salmiaton Ali obtained her B.Sc. and Ph.D. both in Chemical Engineering from Polytechnic University, New York, USA in 1994 and UMIST, Manchester, UK in 2004, respectively. Currently she works as a lecturer at Universiti Putra Malaysia, specializing in solid waste treatment and recovery.

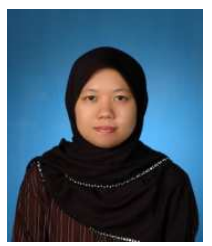

Aida Isma graduated in Bachelor of Chemical Engineering in 2001 and MSc. in Environmental Engineering in 2003 from Universiti Putra Malaysia. She is currently a $\mathrm{PhD}$ student in Environmental Engineering in the same university.

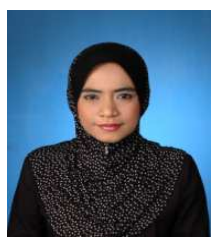

Hazmin Mansor obtained her Bachelor Degree in Chemical Engineering in 2001 and Msc. Environmental Engineering in 2003 from Universiti Putra Malaysia. Currently she is undergoing her $\mathrm{PhD}$ in Civil Engineering majoring in Biological Nutrient Removal for Wastewater Treatment in Universiti Teknologi Malaysia. 